\title{
Comparative Study between Activated Carbon and Biochar for Phenol Removal from Aqueous Solution
}

\author{
Moammar Elbidi, ${ }^{\mathrm{a}, \mathrm{b}, *}$ Agab Hewas, ${ }^{\mathrm{c}}$ Rajab Asar, ${ }^{\mathrm{d}}$ and Mohamad Amran Mohd Salleh ${ }^{\mathrm{a}, \mathrm{e}}$ \\ Removal of phenol from wastewater using local biochar (BC) was \\ investigated, while using activated carbon (AC) as a reference material. \\ The main parameters affecting the sorption process were initial \\ concentration, contact time, $\mathrm{pH}$, and temperature. Statistical analysis of \\ the results showed that the maximum removal percent when using $A C$ and \\ BC were $95 \%$ and $55 \%$, respectively. Experimental data showed that the \\ removal of phenol has fast kinetics and reached equilibrium within 5 \\ minutes. The Langmuir and Freundlich isotherm models were applied to \\ fit the adsorption experimental data. Pseudo-first order and pseudo- \\ second order kinetic models were employed.
}

Keywords: Wastewater treatment; Adsorption; Phenol removal; Activated carbon; Biochar; Langmuir and Freundlich isotherm models

Contact information: a: Department of Chemical and Environmental Engineering, Universiti Putra Malaysia, 43400 UPM, Serdang, Selangor, Malaysia; $b$ : Department of Chemical and Petroleum Engineering, Faculty of Engineering, Elmergib University, Alkhoms, Libya; c: Department of Chemistry, Faculty of Science, Elmergib University, Alkhoms, Libya; d: Department of Earth and Environmental Science, Faculty of Science, Elmergib University, Alkhoms, Libya; e: Institute of Advanced Technology, Universiti Putra Malaysia, 43400 UPM Serdang, Selangor, Malaysia; *Corresponding author: asalleh@upm.edu.my

\section{INTRODUCTION}

Phenol and its compounds are considered pollutants, as they are toxic and harmful to the environment even at low concentrations. Almost all phenolic compounds have high resistance to biodegradation. For that, another type of degradation is sometimes required (Polat et al. 2006; Lin and Juang 2009; Abdelkreem 2013; Gilani et al. 2019). Consequently, wastewater containing phenol compounds must be treated before it is drained into a water stream (Ahmaruzzaman 2008; Younis et al. 2020). Various methods have been suggested for the treatment of wastewater, including physical, chemical, and biological methods. These methods are based on principles such as filtration, sedimentation, precipitation and coagulation, osmosis, ion exchange, and adsorption (González García 2018; Sathya Priya and Sureshkumar 2020). The adsorption technique is an efficient method for removing phenol compounds, because it is an easy, accessible, and reusable method (Roostaei and Tezel 2004; Xie et al. 2020).

Finding an efficient adsorbent is the most challenging task facing researchers. Because of its high adsorption capacity and effectiveness, activated carbon is the most frequently used among all adsorbents (Polat et al. 2006; Lin and Juang 2009). Recently, consideration has focused on sustainable options such as biochar (Lee et al. 2019; Lawal et al. 2020). Biochar has been used in treatment of wastewater that contains organic compounds, including phenol compounds (Lawal et al. 2021). This adsorbent was used due to its unique properties (low cost, high efficiency, operating over a wide range of 
temperature, and low energy consumption) (Sabzehmeidani et al. 2021). Many studies have been conducted to obtain biochar from agricultural waste and other wastes: including food waste (Lee et al. 2019), Citrullus colocynthis waste ash (Qasemi et al. 2018), oil palm (Lawal et al. 2020), sludge obtained in the treatment of coking wastewater (Zhang et al. 2018), chicken manure (Thang et al. 2019), cattle manure and sawdust (Wang et al. 2020), and sewage sludge (Liang et al. 2020). The surface area of the adsorbent material depends mainly on the conditions of preparation of this material (such as time and temperature), followed by the activation process. The activation can make use of several types of chemicals (activating agents), including $\mathrm{K}_{2} \mathrm{CO}_{3}, \mathrm{NaOH}, \mathrm{ZnCl}_{2}$, and $\mathrm{KOH}$. In general, it has been observed that the average pore size increased when the temperature increased (Gale et al. 2021).

The main objective of this research was to adsorb phenol compounds using two different materials, activated carbon and biochar, and to investigate their adsorption ability of phenol compounds under different parameters. What distinguishes this study is the accurate identification of all the factors that can affect the adsorption process. Moreover, in order to analyze the adsorption process, experimental equilibrium isotherms were fitted with Langmuir and Freundlich equations and for detecting the kinetic process pseudo-first order and pseudo-second order kinetic models were also used.

\section{EXPERIMENTAL}

\section{Preparation of Adsorbent Materials}

Biochar was produced by drying olive branches in an oven at $120^{\circ} \mathrm{C}$ for $24 \mathrm{~h}$, then heating the material under oxygen-limited conditions at $500{ }^{\circ} \mathrm{C}$ for an hour. Commercial activated carbon for comparative study of adsorption capacity was supplied by Honeywell Riedel-de Haën AG, Germany. The activated carbon was used without further cleaning. The adsorbents were sieved to 500 micrometers.

\section{Adsorbate}

A stock solution of phenol was prepared by dissolving $1 \mathrm{~g}$ of phenol in $1000 \mathrm{~mL}$ of distilled water. The solution was then diluted to appropriate concentrations for each experiment. A calibration curve with different concentrations ranging from 0 to $100 \mathrm{ppm}$ was obtained. An UV Spectrophotometer (Model 6305, Jenway, Stone, UK) was used for investigation of phenol concentration at wavelength of $269 \mathrm{~nm}$. Residual phenol concentration was analyzed via standard methods of ultraviolet/visible spectroscopy at 269 $\mathrm{nm}$ using a spectrophotometer.

\section{Adsorption Procedure}

Adsorption experiments were performed at different temperature ranges. The experiments were conducted by adding $0.5 \mathrm{~g}$ of adsorbent material to $20 \mathrm{~mL}$ of phenol solution of $100 \mathrm{ppm}$ concentration in a conical flask. Then these flasks were placed on an orbital shaker (Johanna Ottogmbh, ks50a, 6171BR00525, Germany); the shaker speed was fixed at $200 \mathrm{rpm}$ for all samples. The $\mathrm{pH}$ scale of phenol solution was set at different $(3,5$, 7, 9, and 11). The contact time of phenol removal was 5 minutes. The adsorbents were filtered from the solutions by a normal filtration method. Then the phenol removal percentages ( $R$ values) were evaluated from initial concentrations $\left(C_{0}\right)$ and the equilibrium concentration $(C)$ of phenol as in $(\mathrm{Eq} 1)$, 


$$
R=\frac{\left(C_{0}-C\right)}{C_{0}} * 100
$$

where $R(\%)$ is the phenol removal percentage, $C_{\mathrm{o}}(\mathrm{mg} / \mathrm{L})$ is the initial concentration of phenol, and $C(\mathrm{mg} / \mathrm{L})$ is the concentration of phenol at equilibrium.

\section{RESULTS AND DISCUSSION}

\section{Calibration Curve}

The phenol calibration curve was used to estimate the concentration of phenol that remained after the extraction process by comparing the phenol absorbance.

Table 1. Phenol Absorbance vs. Phenol Concentrations

\begin{tabular}{|c|c|}
\hline Phenol Concentration (ppm) & Absorbance \\
\hline 0 & 0 \\
\hline 5 & 0.045 \\
\hline 10 & 0.114 \\
\hline 25 & 0.317 \\
\hline 50 & 0.611 \\
\hline 100 & 1.231 \\
\hline
\end{tabular}

Table 2. Absorption Value $(\mathrm{mg} / \mathrm{g})$ for Samples at Different Temperature and $\mathrm{pH}$

\begin{tabular}{|c|c|c|c|c|c|c|c|c|c|}
\hline \multicolumn{2}{|c|}{ Temperature } & \multicolumn{2}{c|}{$25\left({ }^{\circ} \mathrm{C}\right)$} & \multicolumn{2}{c|}{$35\left({ }^{\circ} \mathrm{C}\right)$} & \multicolumn{2}{c|}{$45\left({ }^{\circ} \mathrm{C}\right)$} & \multicolumn{2}{c|}{$55\left({ }^{\circ} \mathrm{C}\right)$} \\
\hline \multicolumn{2}{|c|}{ Adsorbents } & $\mathrm{AC}$ & $\mathrm{BC}$ & $\mathrm{AC}$ & $\mathrm{BC}$ & $\mathrm{AC}$ & $\mathrm{BC}$ & $\mathrm{AC}$ & $\mathrm{BC}$ \\
\hline \multirow{4}{*}{$\mathrm{pH}$} & 3 & 63 & 65 & 69.5 & 70.5 & 72 & 74 & 76 & 78 \\
\cline { 2 - 11 } & 5 & 55 & 58 & 60 & 62 & 62 & 64 & 70 & 73 \\
\cline { 2 - 11 } & 7 & 39 & 40.5 & 45 & 48 & 53 & 58 & 66 & 71 \\
\cline { 2 - 11 } & 9 & 44 & 48 & 52 & 55 & 67 & 71 & 74 & 80 \\
\cline { 2 - 10 } & 11 & 48 & 51 & 56 & 59 & 70 & 74 & 77 & 81 \\
\hline
\end{tabular}

Table 3. Concentrations vs. Adsorption for each Sample at $\mathrm{pH}=7$

\begin{tabular}{|c|c|c|c|}
\hline Temperature $\left({ }^{\circ} \mathrm{C}\right)$ & Adsorbents & Removal & Concentration (ppm) \\
\hline \multirow{2}{*}{25} & Activated carbon & 39 & 61 \\
\cline { 2 - 4 } & Biochar & 40.5 & 59.5 \\
\hline \multirow{2}{*}{35} & Activated carbon & 45 & 55 \\
\cline { 2 - 4 } & Biochar & 48 & 52 \\
\hline \multirow{2}{*}{45} & Activated carbon & 53 & 47 \\
\cline { 2 - 4 } & Biochar & 58 & 42 \\
\hline \multirow{2}{*}{55} & Activated carbon & 66 & 34 \\
\cline { 2 - 4 } & Biochar & 71 & 29 \\
\hline
\end{tabular}

\section{Effect of $\mathrm{pH}$}

The $\mathrm{pH}$ value is the most important parameters affecting the adsorption method of phenol. Figure 1 presents the effect of $\mathrm{pH}$ on the adsorption of phenol. The phenol uptake by activated carbon and biochar increased gradually in the $\mathrm{pH}$ range of 3 to 7 , and then it noticeably decreased with increasing $\mathrm{pH}$ from 7 to 11 . The high solubility in water for 
phenolate at $\mathrm{pH}$ value $(>7)$ leads to a weak adsorption process on the biochar surface. These results were in good agreement with the reported results in the literature (Bohli et al. 2013; Gilani et al. 2019; Xie et al. 2020). The best pH value for adsorption was 7; therefore, this value was used for all the other experiments. Hence, Table 3 reports the final concentration of phenol for all samples at $\mathrm{pH}=7$.

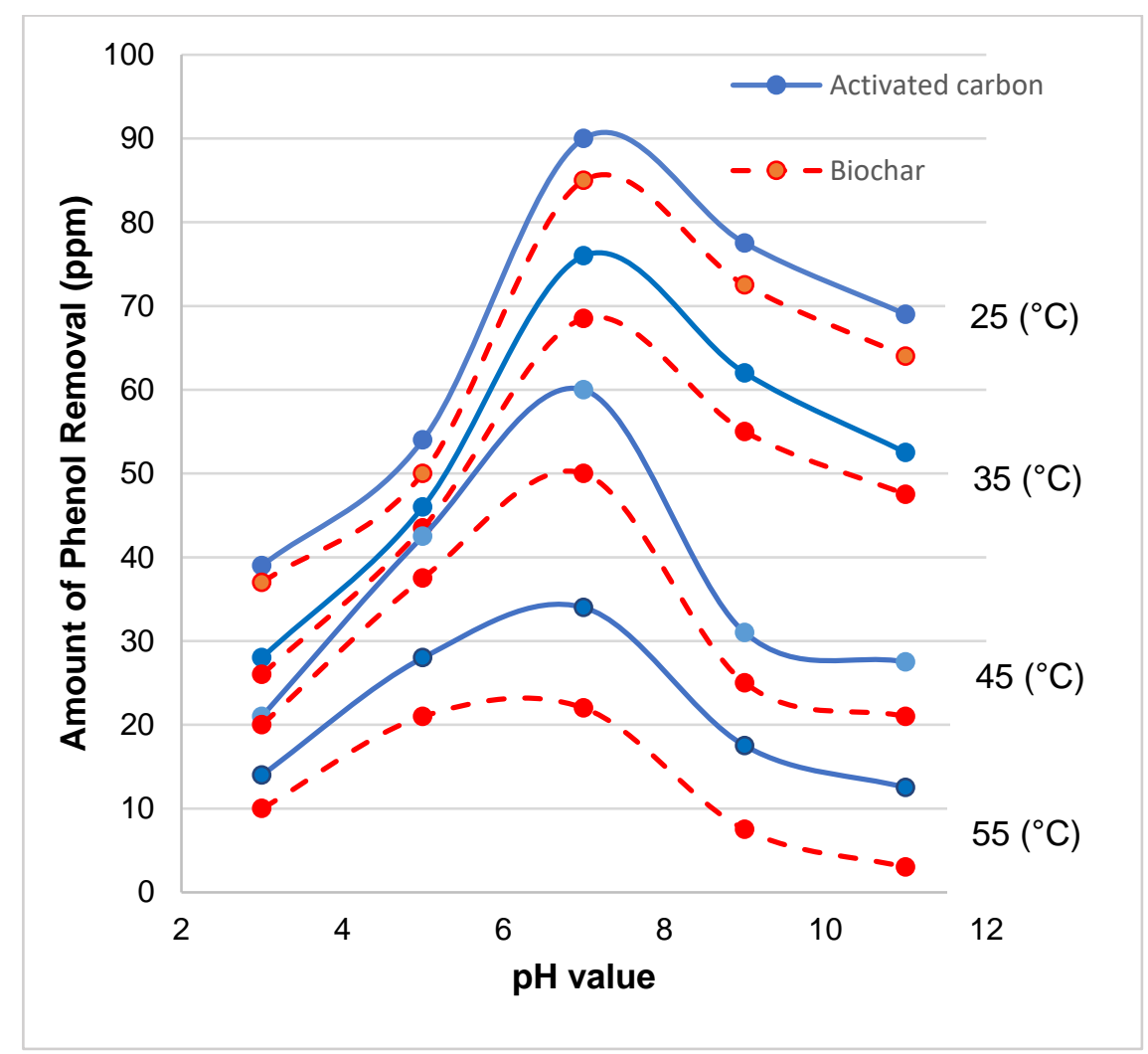

Fig. 1. Effect of $\mathrm{pH}$ variation on phenol removal at different temperature

\section{Effect of Temperature Variation on Phenol Removal}

Markedly increasing adsorption process temperature led to decreasing phenol removal for both adsorbents as shown in Table 4. Similar results have been reported by others (Lin and Juang 2009; Xie et al. 2020)

Table 4. Amount of Phenol Removed vs. Different Temperature Range

\begin{tabular}{|c|c|c|}
\hline \multirow{2}{*}{ Temperature $\left({ }^{\circ} \mathrm{C}\right)$} & \multicolumn{2}{|c|}{ Amount of Phenol Removal (ppm) } \\
\cline { 2 - 3 } & Activated Carbon & Biochar \\
\hline 25 & 61 & 59.5 \\
\hline 35 & 55 & 52 \\
\hline 45 & 47 & 42 \\
\hline 55 & 34 & 29 \\
\hline
\end{tabular}




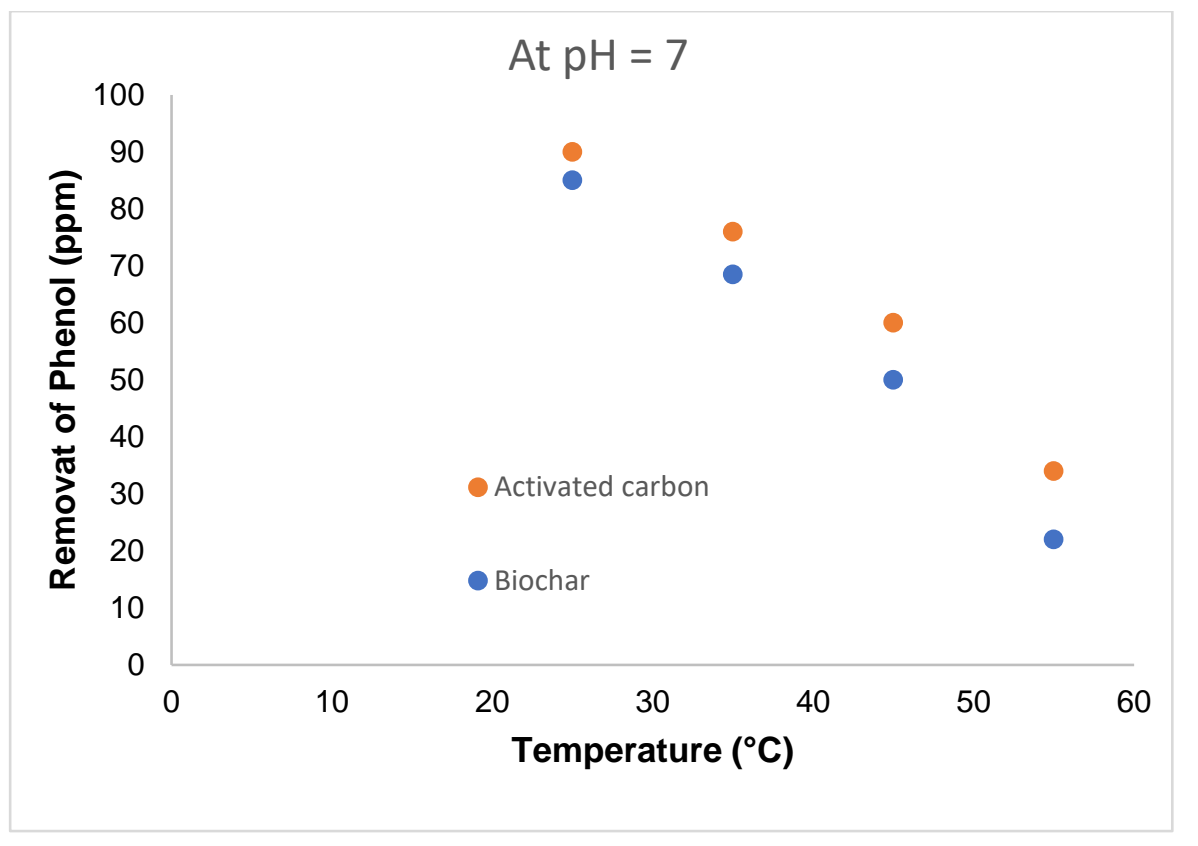

Fig. 2. Effect of temperature variation on phenol removal at the best $\mathrm{pH}$ value of 7

\section{Adsorption Isotherms}

Several isotherm equations have been used to describe equilibrium adsorption. The most widely used are the Langmuir and Freundlich isotherms. These two isotherms were used in this work to describe the relationship between the uptake amount of phenol $(0.5 \mathrm{~g}$ of adsorbent) and the remaining concentration in solution, as reported in figures below.

Table 5. Change in Phenol Concentration and Uptake Amount on Biochar

\begin{tabular}{|c|c|c|c|c|c|}
\hline$C_{\mathrm{e}}(\mathrm{mg} / \mathrm{L})$ & $q_{\mathrm{e}}(\mathrm{mg} / \mathrm{g})$ & $1 / C_{\mathrm{e}}(\mathrm{L} / \mathrm{mg})$ & $1 / q_{\mathrm{e}}(\mathrm{g} / \mathrm{mg})$ & $\log C_{\mathrm{e}}$ & $\log q_{\mathrm{e}}$ \\
\hline 33 & 17 & 0.030 & 0.058 & 1.518 & 1.230 \\
\hline 41 & 19 & 0.024 & 0.052 & 1.612 & 1.278 \\
\hline 49 & 21 & 0.020 & 0.047 & 1.690 & 1.322 \\
\hline 57 & 23 & 0.017 & 0.043 & 1.755 & 1.361 \\
\hline 64 & 26 & 0.015 & 0.038 & 1.806 & 1.414 \\
\hline 71 & 29 & 0.014 & 0.034 & 1.851 & 1.462 \\
\hline
\end{tabular}

\section{Langmuir isotherm}

Linear form of Langmuir isotherm is presented in Eq. 2 (Cazetta et al. 2011),

$$
\frac{1}{q_{e}}=\frac{1}{Q}+\frac{1}{K Q} * \frac{1}{C_{e}}
$$

where $q_{\mathrm{e}}(\mathrm{mg} / \mathrm{g})$ is the phenol adsorption, $Q(\mathrm{mg} / \mathrm{g})$ signifies the phenol monolayer capacity, $K(\mathrm{~L} / \mathrm{mg})$ is a constant related to energy of adsorption, and $C_{\mathrm{e}}(\mathrm{mg} / \mathrm{L})$ is the equilibrium concentration of remaining phenol at $q_{\mathrm{e}}$.

If the adsorption system follows a Langmuir adsorption model, then a plot of $\left(1 / q_{\mathrm{e}}\right)$ versus $\left(1 / C_{\mathrm{e}}\right)$ would produce a straight line from which $Q$ and $K$ could be evaluated from the $y$-intercept of the line and the slope of the line, respectively. 


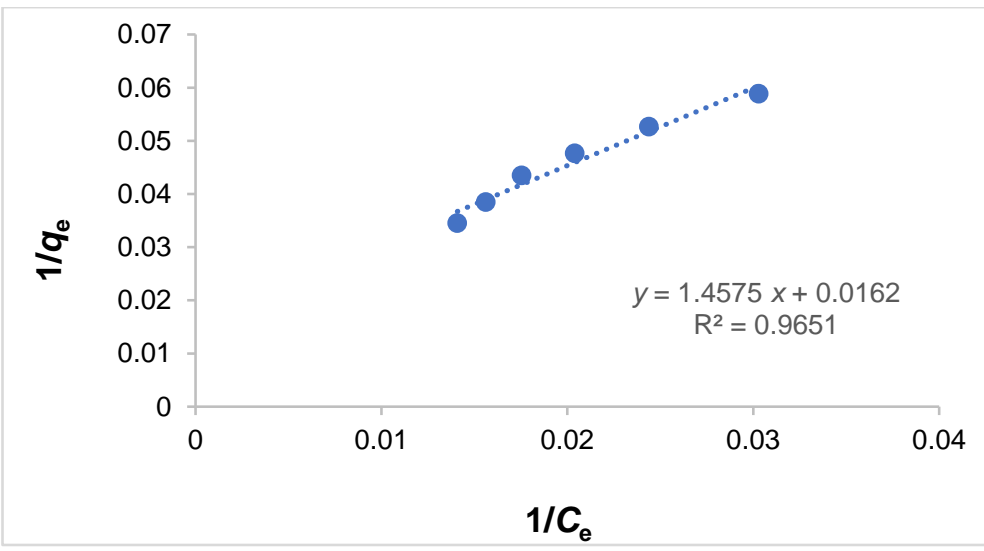

Fig. 3. Langmuir adsorption isotherm for phenol adsorption

\section{Freundlich isotherm}

The linear form of the Freundlich isotherm equation is presented in Eq. 3 (Foo and Hameed 2010),

$$
\log q_{e}=\log K+\frac{1}{n} \log C_{e}
$$

where $q_{\mathrm{e}}(\mathrm{mg} / \mathrm{g})$ is the phenol adsorption, $C_{\mathrm{e}}(\mathrm{mg} / \mathrm{l})$ is the equilibrium concentration of remaining phenol at $q_{\mathrm{e}}, K$ is an adsorption capacity, and $n$ is an adsorption intensity.

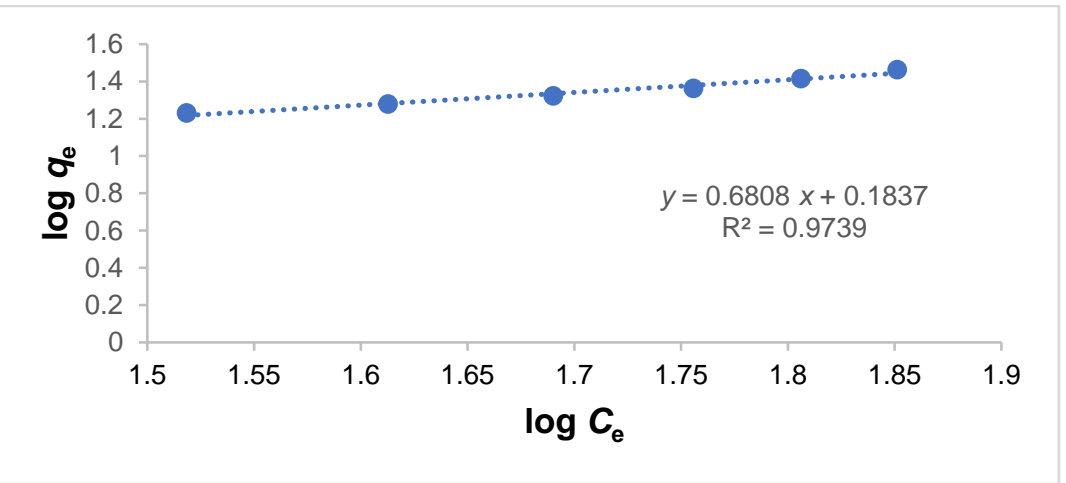

Fig. 4. Freundlich adsorption isotherm for phenol adsorption

Table 6. Isotherm Parameters for Phenol Adsorption

\begin{tabular}{|c|c|c|c|c|c|}
\hline \multicolumn{3}{|c|}{ Langmuir Isotherm } & \multicolumn{3}{c|}{ Freundlich Isotherm } \\
\hline$Q_{\mathrm{m}}(\mathrm{mg} / \mathrm{g})$ & $K_{\mathrm{L}}(\mathrm{l} / \mathrm{mg})$ & $\mathrm{R}^{2}$ & $K_{\mathrm{F}}(\mathrm{mg} / \mathrm{kg})$ & $n$ & $\mathrm{R}^{2}$ \\
\hline 61.72 & 0.0111 & 0.9651 & 1.5265 & 1.4688 & 0.9739 \\
\hline
\end{tabular}

Something to consider, when doing further work in the future, is that a data that better span the range of time, especially at short times, may allow a better discrimination between the Langmuir and Freundlich isotherms. 


\section{Kinetic Adsorption Models}

The kinetic aspects of adsorption were studied at a fixed initial phenol concentration of $50 \mathrm{mg} / \mathrm{L}$ and for various contact times. In order to determine the kinetic model parameters for two possible rate orders.

Table 7. Change in Adsorbed Amount of Phenol with Increasing in Contact Time

\begin{tabular}{|c|c|c|c|c|c|}
\hline$q_{\mathrm{e}}(\mathrm{mg} / \mathrm{g})$ & $q_{\mathrm{t}}(\mathrm{mg} / \mathrm{g})$ & $\begin{array}{c}\left(q_{\mathrm{e}}-q_{\mathrm{t}}\right) \\
(\mathrm{mg} / \mathrm{g})\end{array}$ & $\begin{array}{c}1 /(\mathrm{qe}-\mathrm{qt}) \\
(\mathrm{g} / \mathrm{mg})\end{array}$ & $t(\mathrm{~h})$ & $\ln \left(q_{\mathrm{e}}-q_{\mathrm{t}}\right)$ \\
\hline 19 & 16 & 3 & 0.33 & 0.1 & 1.098 \\
\hline 22 & 19 & 3 & 0.33 & 1 & 1.098 \\
\hline 25 & 21 & 4 & 0.25 & 1.5 & 1.386 \\
\hline 31 & 26 & 5 & 0.2 & 2 & 1.609 \\
\hline 39 & 32 & 7 & 0.14 & 2.5 & 1.945 \\
\hline 49 & 40 & 8.9 & 0.11 & 3 & 2.186 \\
\hline
\end{tabular}

Pseudo-first order kinetic model

Linear form of pseudo-first order kinetic model given by Lagergren (Ho and Mckay 1998), equation is expressed as,

$$
\ln \left(q_{\mathrm{e}}-q_{\mathrm{t}}\right)=\ln q_{\mathrm{e}}-k_{1} t
$$

where $q_{\mathrm{e}}(\mathrm{mg} / \mathrm{g})$ and $q_{\mathrm{t}}(\mathrm{mg} / \mathrm{g})$ are the amounts of adsorbate uptake per mass of adsorbent at equilibrium and at any time $t(\mathrm{~min})$, respectively, and $k_{1}\left(\mathrm{~min}^{-1}\right)$ is the rate constant for pseudo-first order equation. Plotting $\ln \left(q_{\mathrm{e}}-q_{\mathrm{t}}\right)$ versus $t$ will get a slope of $-k_{1}$ and intercept of $\ln \left(q_{\mathrm{e}}\right)$.

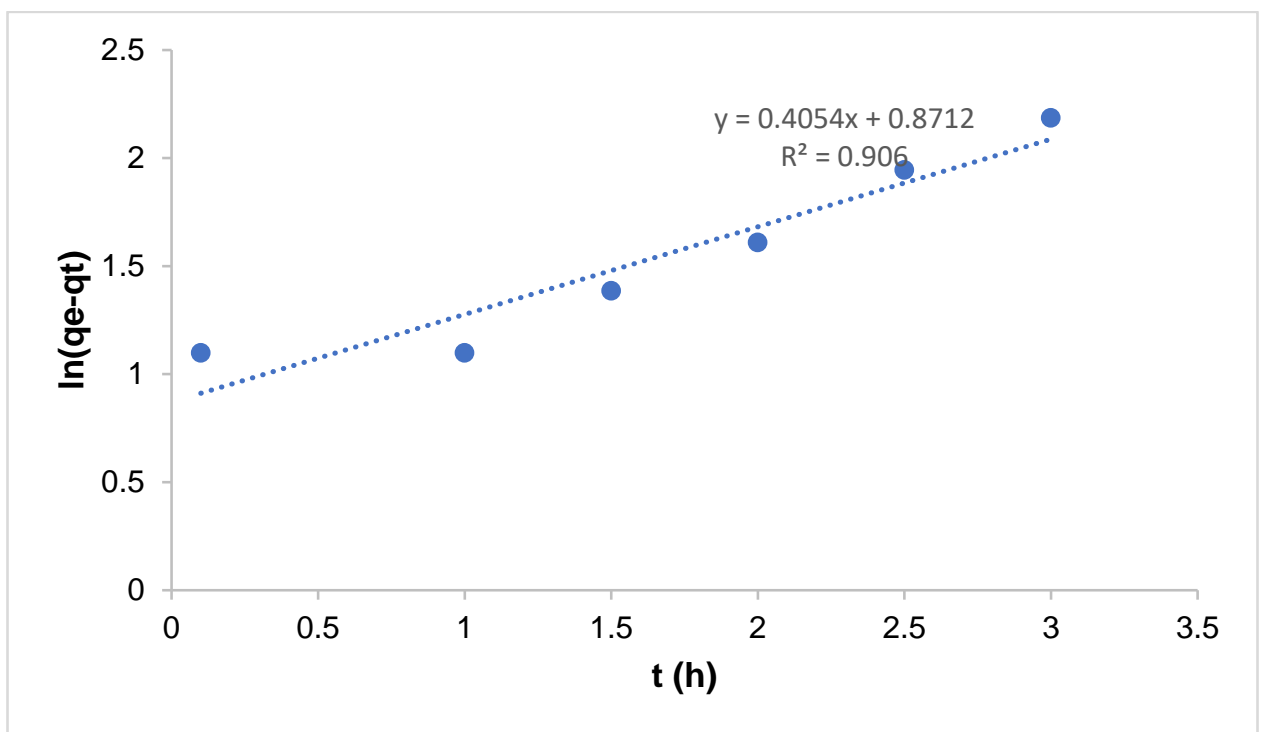

Fig. 5. Pseudo-first order kinetics plot for phenol adsorption

Pseudo-second order kinetic model

The linear form of pseudo-second order kinetic model equation was given by Ho and Mckay 1998), equation is expressed as,

$$
\frac{1}{q_{e}-q_{t}}-\alpha=k_{2} \mathrm{t}
$$


where $k_{2}$ is the pseudo second order rate constant the value of $k_{2}$ depends on the operating conditions initial $\mathrm{pH}$ and solution concentration, temperature etc.

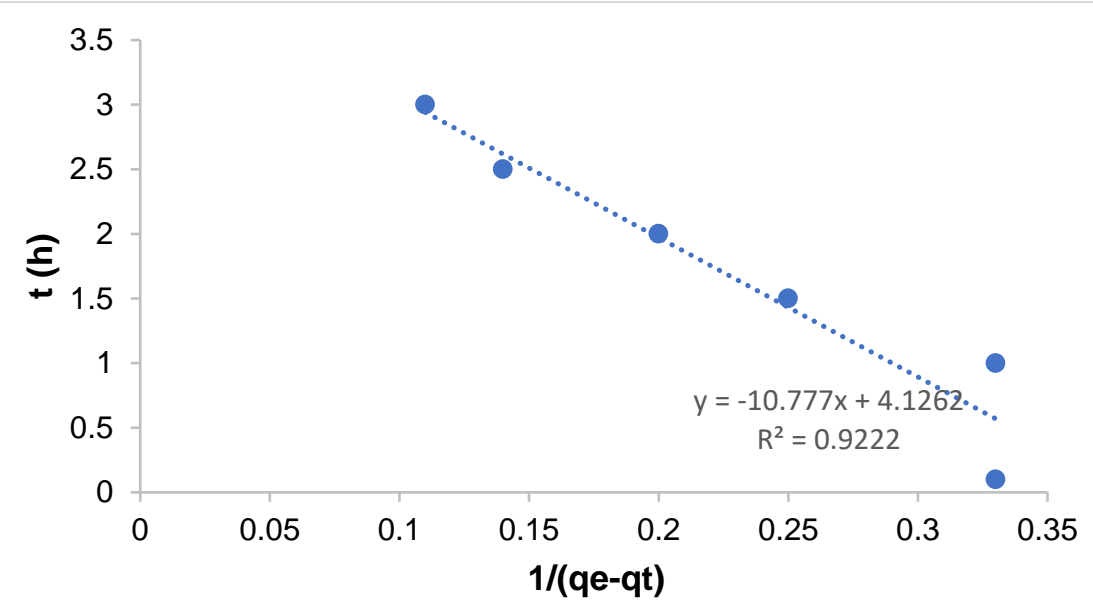

Fig. 6. Pseudo-second order kinetics plot for phenol adsorption

Table 8 compares the coefficient of determination $\left(\mathrm{R}^{2}\right)$ values and adsorption capacity $\left(q_{\mathrm{e}}\right)$ of the pseudo-first and pseudo-second order models; the $\mathrm{R}^{2}$ of the pseudopseudo-second order was greater than that for first order. Furthermore, the chemical reaction appears to be significant in the rate-controlling step, and the best correlation of the experimental data is obtained by pseudo-second-order chemical reaction kinetics.

Table 8. Kinetic Parameters Obtained from Pseudo First Order and Pseudo Second Order Kinetic Models

\begin{tabular}{|c|c|c|c|}
\hline \multicolumn{2}{|c|}{ Pseudo First Order } & \multicolumn{2}{c|}{ Pseudo Second Order } \\
\hline$K_{1}$ & $\mathrm{R}^{2}$ & $K_{2}$ & $\mathrm{R}^{2}$ \\
\hline 0.405 & 0.906 & -10.777 & 0.9222 \\
\hline
\end{tabular}

\section{CONCLUSIONS}

1. This study showed that biochar is a suitable adsorbent material to remove the harmful phenol compounds from polluted water.

2. Increasing adsorption process temperature causes the phenol removal to decrease, and the maximum value of phenol removal was at room temperature.

3. Both the Freundlich and Langmuir isotherms were found to be good ways to represent the equilibrium adsorption amounts as a function of phenol remaining in solution.

\section{REFERENCES CITED}

Abdelkreem, M. (2013). "Adsorption of phenol from industrial wastewater using olive mill waste," APCBEE Procedia 5, 349-357. DOI: 10.1016/j.apcbee.2013.05.060. Ahmaruzzaman, M. (2008). "Adsorption of phenolic compounds on low-cost adsorbents: 
A review," Advances in Colloid and Interface Science 143 (1-2), 48-67. DOI: 10.1016/j.cis.2008.07.002.

Bohli, T., Nuria Fiol, I. V., and Abdelmottaleb, O. (2013). "Adsorption on activated carbon from olive stones: Kinetics and equilibrium of phenol removal from aqueous solution," Chemical Engineering \& Process Technology 4(6), 3-7. DOI: 10.4172/2157-7048.1000165.

Cazetta, A. L., Vargas, A. M. M., Nogami, E. M., Kunita, M. H., Guilherme, M. R., Martins, A. C., Silva, T. L., Morael, J. C. G., and Almeida, V. C. (2011). "NaOHactivated carbon of high surface area produced from coconut shell: Kinetics and equilibrium studies from the methylene blue adsorption," Chemical Engineering Journal 174, 117-125. DOI: 10.1016/j.cej.2011.08.058.

Foo, K. Y., and Hameed, B. H. (2010). "Insights into the modeling of adsorption isotherm systems," Chemical Engineering Journal 156, 2-10. DOI: 10.1016/j.cej.2009.09.013.

Gale, M., Nguyen, T., Moreno, M., and Gilliard-Abdulaziz, K. L. (2021). "Physiochemical properties of biochar and activated carbon from biomass residue: Influence of process conditions to adsorbent properties," ACS Omega DOI: 10.1021/acsomega.1c00530.

Gilani, A. G., Ghanadzadeh G. H., Azmoon, P., and Chaibakhsh, N. (2019). "Phenol adsorption from aqueous phase onto prepared low-cost carbons from natural sources: A comparative study," Physical Chemistry Research 7(2), 327-346. DOI: 10.22036/pcr.2019.160071.1572.

González García, P. (2018). "Activated carbon from lignocellulosics precursors: A review of the synthesis methods, characterization techniques and applications," Renewable and Sustainable Energy Reviews 82(August 2017), 1393-1414. DOI: 10.1016/j.rser.2017.04.117.

Ho, Y. S., and Mckay, G. (1998). "A comparison of chemisorption kinetic models applied to pollutant removal on various sorbents," Process Safety and Environmental Protection: Transactions of the Institution of Chemical Engineers, Part B 76 (November), 332-340.

Lawal, A. A., Hassan, M. A., Abdillah, M., Farid, A., Tengku Yasim-anuar, T. A., Mohd Yusoff, M. Z., Zakaria, M. R., Mokhtar, M. N., and Shirai, Y. (2021). “Adsorption mechanism and effectiveness of phenol and tannic acid removal by biochar produced from oil palm frond using steam," Environmental Pollution 269. DOI: 10.1016/j.envpol.2020.116197.

Lawal, A. A., Hassan, M. A., Ahmad Farid, M. A., Tengku Yasim-Anuar, T. A., Mohd Yusoff, M. Z., Zakaria, M. R., Roslan, A. M., Mokhtar, M. N., and Shirai, Y. (2020). "One-step steam pyrolysis for the production of mesoporous biochar from oil palm frond to effectively remove phenol in facultatively treated palm oil mill effluent," Environmental Technology and Innovation 18, article no. 100730. DOI: 10.1016/j.eti.2020.100730.

Lee, C.-G., Hong, S. H., Hong, S. G., Choi, J. W., and Park, S. J. (2019). "Production of biochar from food waste and its application for phenol removal from aqueous solution," Water, Air, and Soil Pollution 230(3), 13. DOI:10.1007/s11270-019-4125-x.

Liang, J., Xu, X. Y., Zhong, Q. J., Xu, Z. B., Zhao, L., Qiu, H., and Cao, X. D. (2020). "Roles of the mineral constituents in sludge-derived biochar in persulfate activation for phenol degradation," Journal of Hazardous Materials 398 (April), article no. 122861. DOI: 10.1016/j.jhazmat.2020.122861. 
Lin, S. H., and Juang, R. S. (2009). "Adsorption of phenol and its derivatives from water using synthetic resins and low-cost natural adsorbents: A review," Journal of Environmental Management 90(3): 1336-1349. DOI: 10.1016/j.jenvman.2008.09.003.

Polat, H., Molva, M., and Polat, M. (2006). "Capacity and mechanism of phenol adsorption on lignite," International Journal of Mineral Processing 79(4), 264-273. DOI: 10.1016/j.minpro.2006.03.003.

Qasemi, M., Afsharnia, M., Zarei, A., Najafpoor, A. A., Salari, S., and Shams, M. (2018). "Phenol removal from aqueous solution using citrullus colocynthis waste ash," Data in Brief 18, 620-628. DOI: 10.1016/j.dib.2018.03.049.

Roostaei, N., and Tezel, F. H. (2004). "Removal of phenol from aqueous solutions by adsorption," Journal of Environmental Management 70(2), 157-164. DOI: 10.1016/j.jenvman.2003.11.004.

Sabzehmeidani, M. M., Mahnaee, S., Ghaedi, M., Heidari, H., and Roy, V. A. L. (2021). "Carbon based materials: A review of adsorbents for inorganic and organic compounds," Materials Advances. DOI: 10.1039/d0ma00087f.

Sathya Priya, D., and Sureshkumar, V. M. (2020). "Synthesis of Borassus flabellifer fruit husk activated carbon filter for phenol removal from wastewater," International Journal of Environmental Science and Technology 17(2), 829-842. DOI: 10.1007/s13762-019-02325-3.

Thang, P. Q., Jitae, K., Giang, B. L., Viet, N. M., and Huong, P. T. (2019). "Potential application of chicken manure biochar towards toxic phenol and 2,4-dinitrophenol in wastewaters," Journal of Environmental Management 251 (May): article no. 109556. DOI: 10.1016/j.jenvman.2019.109556.

Wang, G. J., Gao, X., Li, Q., Zhao, H. X., Liu, Y. Z., Wang, X. C. C., and Chen, R. (2020). "Redox-based electron exchange capacity of biowaste-derived biochar accelerates syntrophic phenol oxidation for methanogenesis via direct interspecies electron transfer," Journal of Hazardous Materials 390 (Nov. 2019), article no. 121726. DOI: 10.1016/j.jhazmat.2019.121726.

Xie, B. X., Qin, J. H., Wang, S., Li, X., Sun, H., and Chen, W. Q. (2020). "Adsorption of phenol on commercial activated carbons: Modelling and interpretation," International Journal of Environmental Research and Public Health 17(3), 1-13. DOI: 10.3390/ijerph17030789.

Younis, A. M., Elkady, E. M., and Saleh, S. M. (2020). "Novel eco-friendly aminomodified nanoparticles for phenol removal from aqueous solution," Environmental Science and Pollution Research 27(24), 30694-705. DOI: 10.1007/s11356-02009313-y.

Zhang, F. Z., Wu, K. Y., Zhou, H. T., Hu, Y., Preis, S. V., Wu, H. Z., and Wei, C. H. (2018). "Ozonation of aqueous phenol catalyzed by biochar produced from sludge obtained in the treatment of coking wastewater," Journal of Environmental Management 224 (December 2017), 376-386. DOI: 10.1016/j.jenvman.2018.07.038.

Article submitted: March 29, 2021; Peer review completed: June 26, 2021; Revised version received and accepted: August 15, 2021; Published: August 24, 2021.

DOI: $10.15376 /$ biores.16.4.6781-6790 